\title{
Eryngium foetidum, Petroselinum crispum and Coriandrum sativum: New Apiaceae Hosts of Oidiopsis taurica in Brazil
}

\author{
Ailton Reis ${ }^{1 *}$, Carlos A. Lopes ${ }^{1}$, Milton L. Paz Lima² \& Leonardo S. Boiteux ${ }^{1}$ \\ ${ }^{1}$ Embrapa Hortaliças, Cx. Postal 218, CEP 70359-970, Brasília, DF, ${ }^{2}$ UnB, Departamento de Fitopatologia Cx. Postal 4457, \\ CEP 70910-900, Brasília, DF, e-mail: ailton@cnph.embrapa.br
}

(Accepted for publication on 13/02/2004)

Corresponding author: Ailton Reis

\section{RESUMO}

Eryngium foetidum, Petroselinum crispum e Coriandrum sativum: novas hospedeiras de Oidiopsis taurica no Brasil

Relata-se a infecção natural de plantas de chicória da Amazônia (Eryngium foetidum), coentro (Coriandrum sativum) e salsa (Petroselinum crispum), cultivados em casas de vegetação e campo na Embrapa Hortaliças, Brasília, DF, por Oidiopsis taurica. A provável fonte de inóculo foram plantas doentes de pimentão (Capsicum annuum) e tomate (Lycopersicon esculentum) na casa de vegetação e pimentão no campo.
Amazon endive (chicória do Amazonas) or false coriander (Eryngium foetidum L.), parsley (Petroselinum crispum Miller) and coriander (Coriandrum sativum L.) are popular species of the family Apiaceae, except for E.foetidum, used only in the Amazon Region as a substitute for coriander. Plants of these three species were cultivated at Embrapa Hortaliças, Brasilia, DF, under greenhouse and plastic house conditions, for diverse purposes. They developed typical symptoms of powdery mildew, which consisted of chlorotic spots on the leaves, followed by necrosis, on the upper surface and fungal structures on the under surface, when naturally exposed to high inoculum of powdery mildew, produced in green pepper (Capsicum anпиит L.) and tomato (Lycopersicon esculentum Mill.) infected by Oidiopsis taurica E.S. Salmon (Syn.: O. sicula Scalia). Leaves of coriander cultivated in two open fields in Brasilia were also found to show the same symptoms. In all cases, fungal structures taken from infected leaves were examined under a light microscope at Embrapa Hortaliças. Conidia morphology and morphometry were similar to those of $O$. taurica, anamorph of Leveillula taurica Lév. The teleomorph stage was not found on any host. The primary and secondary conidia found on leaves of false coriander, coriander, and parsley measured, respectivelly, $63,56 \mu \mathrm{m} \times 14,95 \mu \mathrm{m}$ and $68,01 \mu \mathrm{m} \times 14,87 \mu \mathrm{m} ; 59,96 \mu \mathrm{m} \times$ $16,14 \mu \mathrm{m}$ e $64,75 \mu \mathrm{m} \times 15,75 \mu \mathrm{m} ; 65,33 \mu \mathrm{m} \times 16,24 \mu \mathrm{m}$ and $63,14 \mu \mathrm{m} \times 15,75 \mu \mathrm{m}$. Conidia from sweet pepper in the greenhouse, which probably supplied the inoculum, measured $65,53 \mu \mathrm{m} \times 16,19 \mu \mathrm{m}$ and $65,02 \mu \mathrm{m} \times 15,70 \mu \mathrm{m}$. Regardless of the host, all the measurements fell in the range designated for $O$. taurica. The wide and increasing host range characteristic of this pathogen is an alert to growers of vegetables and ornamental plants, especially under greenhouse conditions, as observed in recent years for pepper and tomato. This paper corroborates findings of other authors (Café Filho,
A.C. et al., 2001. Oídios de hortaliças. In: Stadnik, M.J. \& Rivera, M.C. Oídios. Embrapa Meio Ambiente. pp.285-302) about the high level of plasticity of $O$. taurica and registers new hosts apparently for the first time in Brazil. It is worthwhile mentioning that carrot (Daucus carota L.), cvs. Brasilia, Alvorada and Nantes, another representative of the Apiaceae, was not infected by the pathogen under the same exposure conditions and even when inoculated with conidia from coriander.

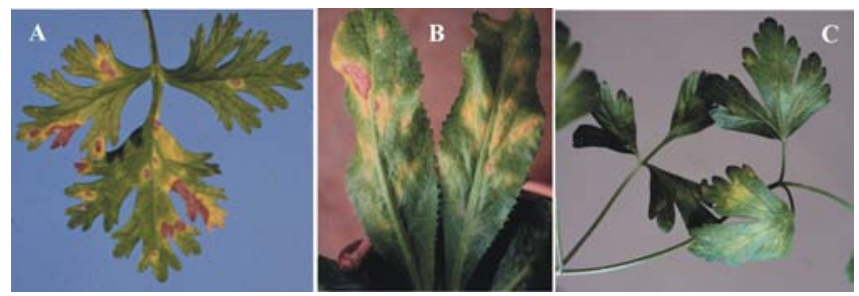

FIG. 1 - Powdery mildew symptoms in coriander (Coriandrum sativum) (A) "chicória do amazonas" (Eryngium foetidum) (B) e parsley (Petroselinum crispum) (C), caused by Oidiopsis taurica.

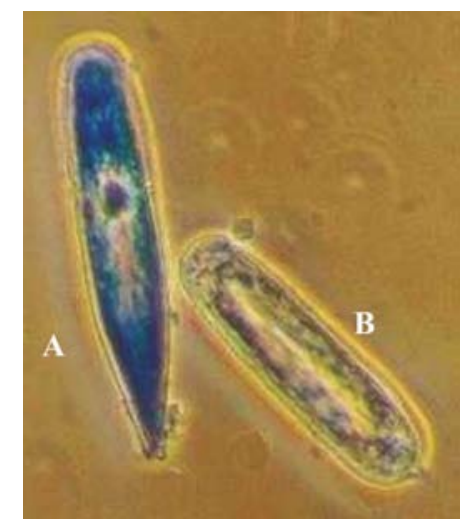

FIG. 2 - Primary (A) and secondary (B) conidia of Oidiopsis taurica. 